\title{
Sosialisasi Online Dampak Negatif Media Sosial Bagi Remaja
}

\author{
Pivit Septiary Chandra, Sonia Sischa Eka Putri, Abdiana Ilosa \\ Arridho Abduh, Ilham Chanra Putra \\ Universitas Islam Negeri Sultan Syarif Kasim Riau \\ E-mail : Septiary01pivit@gmail.com
}

\begin{abstract}
Abstrak
Teknologi dan jejaring sosial atau sering disebut media sosial sudah menjadi bagian dari kehidupan sosial di dunia nyata. Media sosial dapat ditemukan dengan bantuan teknologi komputer, laptop, smartphone dan media komunikasi lainnya. Penggunaan media sosial telah digunakan di berbagai lapisan masyarakat dan berbagai kalangan untuk media interaksi atau promosi dari anak-anak, remaja, hingga dewasa. Remaja merupakan masa transisi dari masa kanak-kanak yang penuh dengan ketergantungan menuju masa pembentukan tanggung jawab. Dalam penggunaanya media sosial digunakan sebagian besar oleh remaja. Masa remaja menjadi perhatian khusus karna akan mempengaruhi perilaku dan kepribadian dimasa depan. Tujuan pengabdian dilakukan untuk memberikan pengetahuan dan wawasan kepada remaja terhadap media sosial dan pengaruhnya, memberikan pembelajaran bagi masayarakat dalam menyikapi media sosial. Metode dilakukan dengan sistem ceramah pendekatan preventif terhadap audiensi terhadap nilai-nilai yang diberikan pemateri.
\end{abstract}

Kata Kunci: Media Sosial, Remaja, Perilaku

\begin{abstract}
Technology and social networks, or what we often call cyberspace, have become part of social life in the real world. social media can be found with the help of computer technology, laptops, smartphones and other communication media. The use of social media has been used at various levels of society and various groups for media interaction or promotion from children, adolescents, to adults. Adolescence is a period of transition from childhood full of dependence to a period of forming responsibilities. In its use, social media is used mostly by adolescents, with this transitional period adolescence becomes a special concern because it will affect their behavior and personality in the future. The purpose of this service is to provide knowledge and insights to adolescents on social media and its effects, to provide learning for the community in responding to social media. The method is carried out with a lecture system with a preventive approach to the audience against the values given by the speaker.
\end{abstract}

Keyword: Social Media, Youth, Behavior 


\section{PENDAHULUAN}

Perkembangan ilmu pengetahuan dan teknologi semakin maju dan mutakhir, pendistribusian informasi serta akses telekomunikasi dan transportasi semakin lebih cepat dan mudah. Internet merupakan salah satu hasil dari kecanggihan dan kemajuan ilmu pengetahuan dan teknologi buatan manusia. Fungsi internet bermacam-macam, dan salah satunya adalah sebagai tempat komunitas jejaring sosial dunia maya. Jejaring sosial merupakan suatu layanan dari sebuah cakupan sistem software internet yang memungkinkan penggunanya dapat berinteraksi dan berbagi data dengan pengguna yang lain dalam skala yang besar.

Berbagai teknologi telah dikembangkan para ilmuan agar memudahkan manusia dalam berkomunikasi. Diawali dengan komunikasi massa yang berupa radio, telepon, televisi, hingga internet. Bahkan dengan kemajuan teknologi sekarang ini, orang dapat berkomunikasi dengan orang lain tiap detik. Baik itu dengan orang yang dikenal hingga orang yang tidak dikenal. Komunikasi tersebut bisa terjadi dengan dua arah maupun satu arah. Teknologi mulai dari radio hingga internet memungkinkan komunikasi yang sulit dilakukan menjadi bisa dilakukan. Salah satu dari sekian banyak temuan para ahli, yang fenomenal adalah media internet.

Keberadaan internet secara tidak langsung menghasilkan sebuah generasi yang baru, yaitu generasi $n e(x t)$. Generasi ini dipandang menjadi sebuah generasi masa depan yang diasuh dan dibesarkan dalam lingkungan budaya baru media sosial digital yang interaktif, yang berwatak menyendiri, berkomunikasi secara personal, melek komputer, dibesarkan dengan videogames, dan lebih banyak waktu luang untuk mendengarkan radio dan televisi (Afriluyanto, 2018).

Tidak seperti orang dewasa yang pada umumnya sudah mampu mem-filter hal-hal baik ataupun buruk dari internet, remaja sebagai salah satu pengguna internet justru sebaliknya. Selain, belum mampu memilah aktivitas internet yang bermanfaat, mereka juga cenderung mudah terpengaruh oleh lingkungan sosial mereka tanpa mempertimbangkan terlebih dahulu efek positif atau negatif yang akan diterima saat melakukan aktifitas internet tertentu (Qomariyah, 2011).

Media sosial/social media atau yang dikenal juga dengan jejaring sosial merupakan bagian dari media baru. Jelas kiranya bahwa muatan interaktif dalam media baru sangatlah tinggi. Media sosial sebagai sebuah media online, dengan para penggunanya bisa dengan mudah berpartisipasi, berbagi, dan menciptakan isi meliputi blog, jejaring sosial, wiki, forum dan dunia virtual. Blog, jejaring sosial dan wiki merupakan bentuk media sosial yang paling umum digunakan oleh masyarakat di seluruh dunia (Watie, 2016). 
Dalam penggunaan media sosial ini erat kaitannya dengan bantuan internet agar tersambung pada jejaring sosial. Dalam hal ini, Jumlah pengguna internet di Indonesia mengalami kenaikan yang cukup signifikan. Berdasarkan Asosiasi Penyelenggara Jasa Internet Indonesia diperoleh data statistik pengguna internet di Indonesia pada tahun 2012 mencapai 63 juta pengguna dan tahun 2013 telah meningkat menjadi 82 juta pengguna, Sedangkan berdasarkan data dari hasil penelitian yang berjudul " Keamanan Penggunaan Media Digital pada Anak dan Remaja di Indonesia” yang dilakukan UNICEF dan Kementerian Komunikasi dan Informatika, pengguna internet di Indonesia yang berasal dari kalangan anak-anak dan remaja diprediksi mencapai 30 juta. Penelitian tersebut juga mencatat ada kesenjangan digital yang kuat antara anak dan remaja yang tinggal di perkotaan dengan yang tinggal di pedesaan. Masih berdasarkan hasil penelitian tersebut didapatkan tiga motivasi bagi remaja untuk mengakses internet, yaitu untuk mencari informasi, untuk terhubung dengan teman (lama dan baru) dan untuk hiburan. Pencarian informasi yang dilakukan sering didorong oleh tugas-tugas sekolah, sedangkan penggunaan media sosial dan konten hiburan didorong oleh kebutuhan pribadi (Pramiyanti et al., 2014).

Fungsi media sosial sekarang tak hanya sekedar saling berkirim pesan dengan orang-orang yang dikenal saja dan menjalin komunikasi dengan orang-orang baru, tetapi juga sebagai tempat memberikan informasi atau tempat mencari informasi. Di zaman new media yang banyak bermunculan media sosial, maka kini media sosial bisa menjadi pilihan bagi stasiun TV sebagai salah satu media untuk melakukan siaran dan menyebarkan informasi. Bisa kita lihat sekarang ada banyak televisi di indonesia bahkan televisi di kampus yang mengunggah hasil tayangan mereka ke YouTube, bahkan terkadang stasiun TV membuat program atau konten khusus mereka yang hanya ditayangkan secara streaming melalui media sosial.

Media sosial seperti Instagram, Facebook, Twitter, dan YouTube kini telah menjadi media sosial yang pupuler di kalangan anak muda saat ini, yang diminati di Indonesia dan juga di seluruh dunia. Masing-masing media sosial tersebut memiliki kelebihan yang diunggulkan seperti contohnya pada YouTube dengan keutamaanya dalam sharing audio visual atau penyebaran pesan berbentuk video ini, YouTube kini mulai semakin diminati oleh masyarakat Indonesia terutama anak muda atau kaum milineal, banyak anak muda di Indonesia sendiri yang mencoba untuk membuat channel YouTube, baik sebagai media untuk informasi, edukasi, bahkan YouTube bisa juga menjadi tempat eksistensi bagi anak muda dan sarana mencari peruntungan untuk menambah penghasilan lewat membuat konten-konten YouTube.

Kehadiran YouTube saat ini membawa pengaruh yang cukup besar, khususnya kepada orang yang memiliki hobi atau keahlian di bidang pembuatan video, kini YouTube bisa menjadi pilihan sebagai tempat untuk mempublikasikan karyanya. YouTube bisa menjadi pilihan karena mudah untuk digunakan, tidak memerlukan biaya yang mahal, 
dapat diakses dimanapun dan kapanpun, tentunya dengan menggunakan media yang mendukung. Dengan adanya media sosial seperti YouTube juga memudahkan mereka yang memiliki hobi di bidang pembuatan video untuk bisa dengan bebas mengunggah karya-karya mereka untuk di publikasikan. Jika video yang telah di unggah tersebut mendapatkan respon dari penonton yang baik, jumlah views dari video tersebut juga kan bisa bertambah, begitu juga dengan jumlah subscribers. Viewers yang banyak tidak menutup kemungkinan untuk mengundang iklan yang masuk. Sama halnya dengan televisi, program acara yang banyak di tonton, juga akan menaikan rating dan mengundang pengiklan untuk memasang iklan.

Di Indonesia saja penguna YouTube dari tahun ketahun terus meningkat drastis dari penontonya sampai juga dengan kreator atau yang disebut dengan youtubers. kekreatifan youtubers membuat pengemarnya tidak mau tertinggal untuk terus mengikuti video-video yang telah dibuat. Banyak fitur didalam YouTube, misalnya kita bisa melihat siaran ulang televisi yang tidak bisa kita tonton saat itu dan YouTube dengan terobosan barunnya dapat menayangkan siaran ulang yang ada di televisi.

Internet dapat menghubungkan orang dari berbagai belahan dunia baik itu yang belum mengenal atau yang sudah mengenal, baik itu dari suku, rasa atau agama yang berbeda, semuannya dapat berkomunikasi langsung melalui media internet. Sebab di dalam media internet memang banyak sarana pendukung bagi manusia untuk melakukan komunikasi. Seperti yang di ungkapkan Tracy (1997:2). Internet adalah semacam jagad raya yang terus menerus berkembang memiliki geografi, cuaca dan budaya sendiri. Dalam dunia cyber ini, berbagai orang dalam penjuru dunia berkomunikasi melalui zona waktu yang berbeda tanpa saling bertatap muka, dan informasinya tersedua 24 jam sehari dari ribuan tempat" (Tracy, 1997).

Salah satu bentuk baru dalam berkomunikasi yang di tawarkan dalam dunia internet adalah media sosial. dimana dengan menggunakan media sosial dalam internet, pengguna bisa meluaskan perkataan ataupun hal dia alami. Karjaluoto (2008:2)

mengungkapkan bahwa istilah media sosial menggambarkan sebuah media sehingga para pengguna dapat dengan mudah berpartisipasi dan memberi kontribusi di dalam media tersebut. Karakteristik umum yang dimiliki setiap media sosial yaitu adanya keterbukaan dialog antar para pengguna. Sosial media dapat dirubah oleh waktu dan diatur ulang oleh penciptanya, atau dalam beberapa situs tertentu, dapat diubah oleh suatu komunitas. Selain itu sosial media juga menyediakan dan membentuk cara baru dalam berkomunikasi (Karjaluoto, 2008).

Pertama, pertumbuhan dan perkembangan fisik pada remaja meliputi perubahan progresif yang bersifat internal maupun eksternal. Perubahan internal meliputi perubahan ukuran alat pencernaan makanan, bertambahnya besar dan berat jantung dan paru-paru, serta bertambah sempurnanya sistem kelenjer endoktrin atau kelamin dan berbagai jaringan tubuh. Adapun perubahan eksternal meliputi bertambahnya tinggi dan 
berat badan, bertambahnya proporsi tubuh, bertambahnya ukuran besarnya organ seks, dan munculnya tanda-tanda kelamin sekunder seperti pada laki-laki tumbuh kumis dan janggut, jakun, bahu dan dada melebar, suara berat, tumbuh bulu di ketiak, di dada, di kaki, di lengan, dan disekitar kemaluan, serta otot-otot menjadi kuat. Sedangkan pada perempuan, tumbuhnya payudara, pinggul membesar, suara menjadi halus.

Kedua, Perkembangan kognitif pada remaja menurut jean Piaget (dalam Desmita, 2008:195) adalah telah mencapai tahap pemikiran operasional formal (Formal Operational Thought) yaitu sudah dapat berfikir secara abstrak dan hipotesis, serta mampu berfikir tentang sesuatu yang akan mungkin terjadi. Mereka juga sudah mampu berfikir tentang sesuatu yang akan mungkin terjadi. Mereka juga sudah mampu memikirkan semua kemungkinan secara sistematik (sebab-akibat) untuk memecahkan dan meyelesaikan masalah-masalah (Desmita, 2008).

Ketiga, perkembangan emosi pada remaja menurut Granville Stanley Hall belum stabil sepenuhnya atau masih sering berubah-ubah. Kadang-kadang mereka semangat bekerja tetapi tiba-tiba menjadi lesu, kadang-kadang mereka terlihat sangat gembira tibatiba menjadi sedih, kadang-kadang mereka terlihat sangat percaya diri tiba-tiba menjadi sangat ragu. Hal ini disebabkan karena mereka memiliki perasaan yang sangat peka terhadap rangsangan dari luar (Mighwar, 2006).

Perkembangan psikososial yang terjadi pada remaja yaitu, remaja mulai mencari identitas jati dirinya. Remaja mulai menyadari adanya rasa kesukaan dan ketidaksukaan atas sesuatu, sudah mempunyai tujuan-tujuan yang ingin dicapai di masa depan, sudah mempunyai kekuatan dan hasrat untuk mengontrol kehidupan sendiri. Dalam menjalin hubungan relasi, remaja lebih banyak menghabiskan waktu dengan teman sebayannya dari pada dengan orang tuannya, sehingga lebih terjalin kedekatan secara pribadi dengan teman sebayannya daripada dengan orangtua. Hal itu membuat mereka lebih suka bercerita masalah-masalah pribadi seperti masalah pacaran dan pandangan-pandangan tentang seksualitas kepada teman sebayannya. Sedangkan masalah-masalah yang mereka ceritakan kepada orang tua hanya masalah sekolah dan rencana karir (Desmita, 2008).

\section{Metode}

Metode yang dipakai dalam pengabdian pada masyarakat ini menggunakan metode ceramah dan orientasi preventif terhadap remaja-remaja yang menjadi audiensi dalam pelaksanaan pengabdian masyarakat ini. Pemilihan remaja yang menjadi peserta diundang secara acak. Undangannya diberikan oleh pelaksana atau tim pengabdian masyarakat secara online.

Pelaksanaan pengabdian masyarakat ini dilakukan pada masa Pandemi virus Covid-19 dimulai pada Oktober hingga Desember 2020. Sehingga sesuai arahan presiden tentang penekanan angka penyebaran virus, harus menjaga jarak, memakai masker, mencuci tangan, dan menghindari kerumunan, maka dari itu tim pelaksana pengabdian 
masyarakat melakukan pengabdian menggunakan aplikasi zoom. Dimulai dari tahap persiapan, pada bulan Oktober 2020, pembuatan proposal pengabdian dan penyusunan Roundown teknis kegiatan. Kegiatan sosialiasasi dilakukan bertahap selama bulan November 2020 dan Tentunya pelaksanaan ini diharapkan tidak mengurangi esensi dari tujuan yang telah dirumuskan tim pelaksana pengabdian terhadap peserta pengabdian masyarakat.

\section{Hasil dan Pembahasan}

Dalam pengabdian ini dapat tergambar hampir keseluruhan peserta merupakan remaja yang sudah aktif dalam media social dan menggunakan platform digital. Mulai dari Instagram, Whatsapp, Facebook, Twitter, Youtube dan Tiktok. Hal ini tergambar dari keikutsertan dan keaktifan setiap peserta dalam kegiatan ini melalui platform yaitu Zoom. Dalam kehidupan dimasa pandemik ini, tergambar jelas bahwa media sosial menjadi kebutuhan pokok setiap remaja, dimana hampir keseluruhan kegiatan dilaksanakan dengan menggunakan media sosial, bersekolah, berinteraksi hingga berkomunikasi dengan teman maupun keluarga.

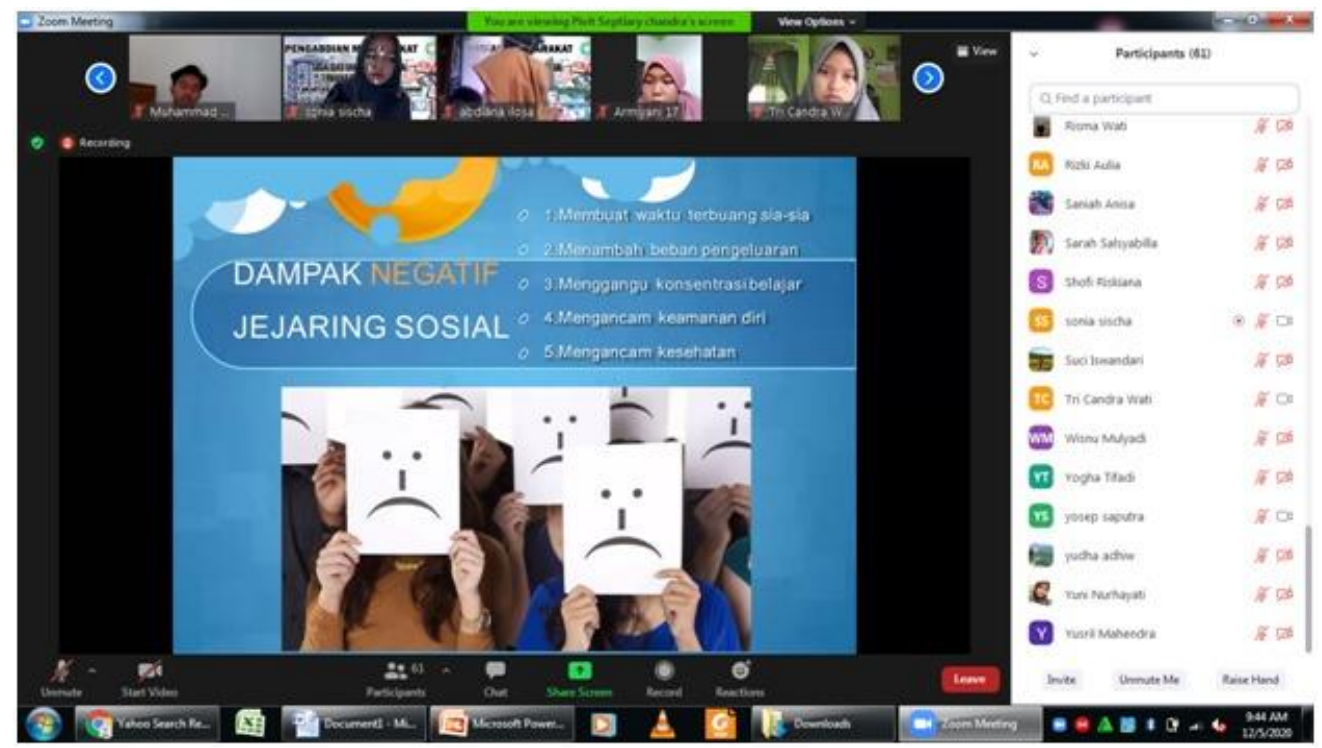

Gambar 1. Foto Sosialisasi Online (Sumber : Dokumentasi Pengabdian) 


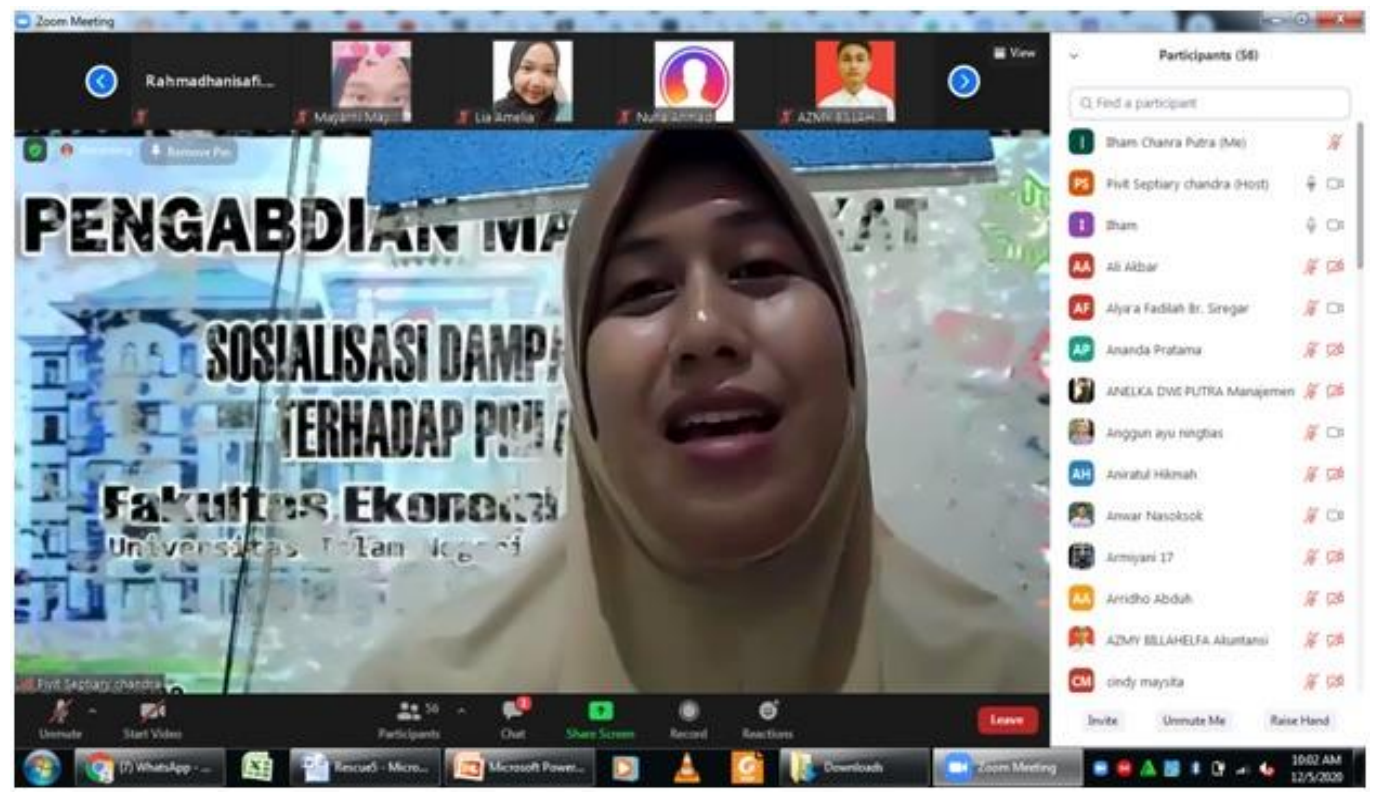

Gambar 2. Pemaparan Materi Sosialisasi Online (Sumber : Dokumentasi Pengabdian)

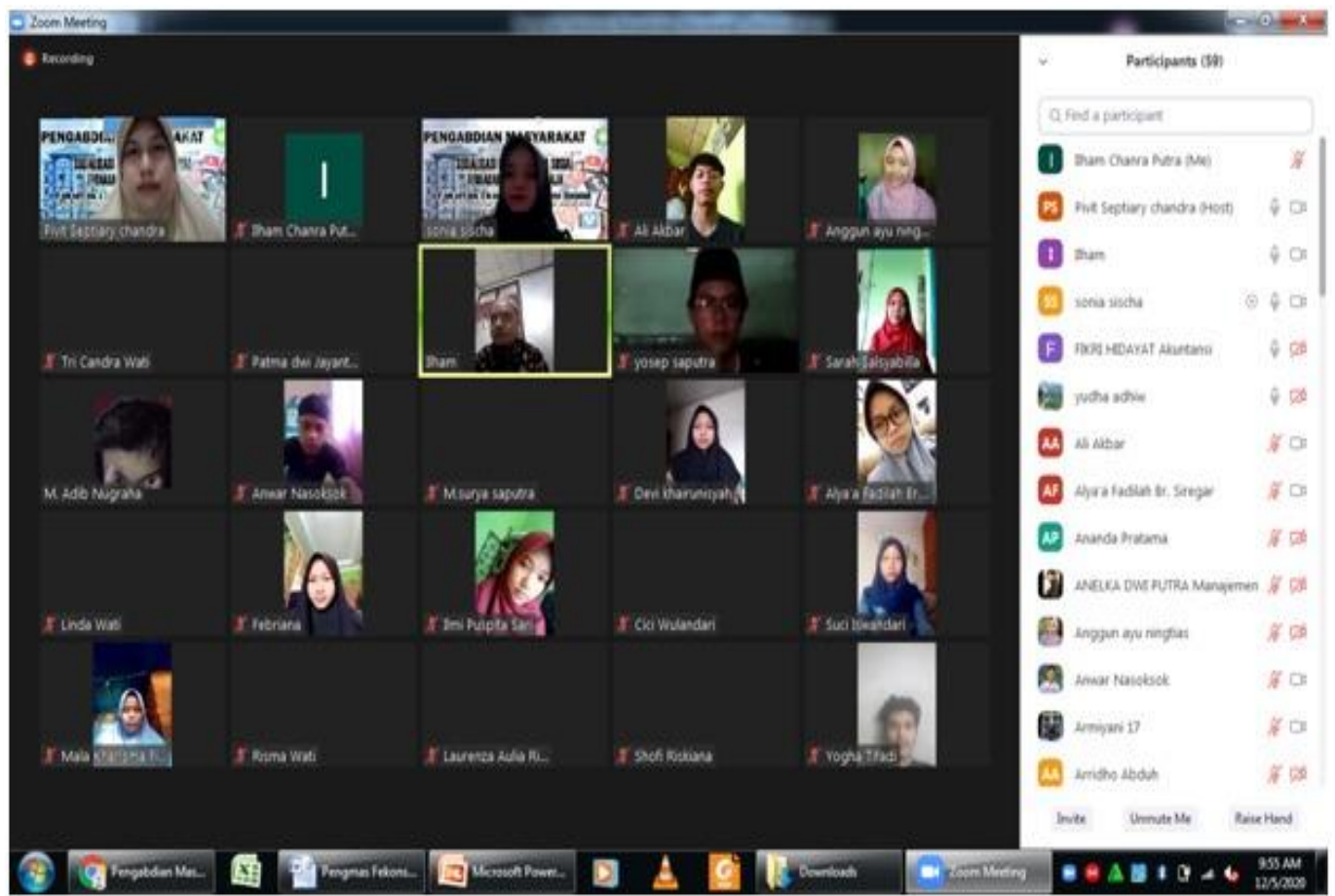

Gambar 3. Peserta Sosialisasi Online (Sumber : Dokumentasi Pengabdian)

Internet merupakan produk teknologi yang banyak dimanfaatkan oleh masyarakat. Sebagai produk teknologi, maka internet dapat memunculkan jenis interaksi sosial baru yang berbeda dengan interaksi sosial sebelumnya. Jika pada masa lalu, masyarakat berinteraksi secara face to face communication, maka dewasa ini masyarakat 
berinteraksi di dalam dunia maya atau melalui interaksi sosial online. Melalui kecanggihan teknologi informasi, maka masyarakat memiliki alternatif lain untuk berinteraksi sosial.

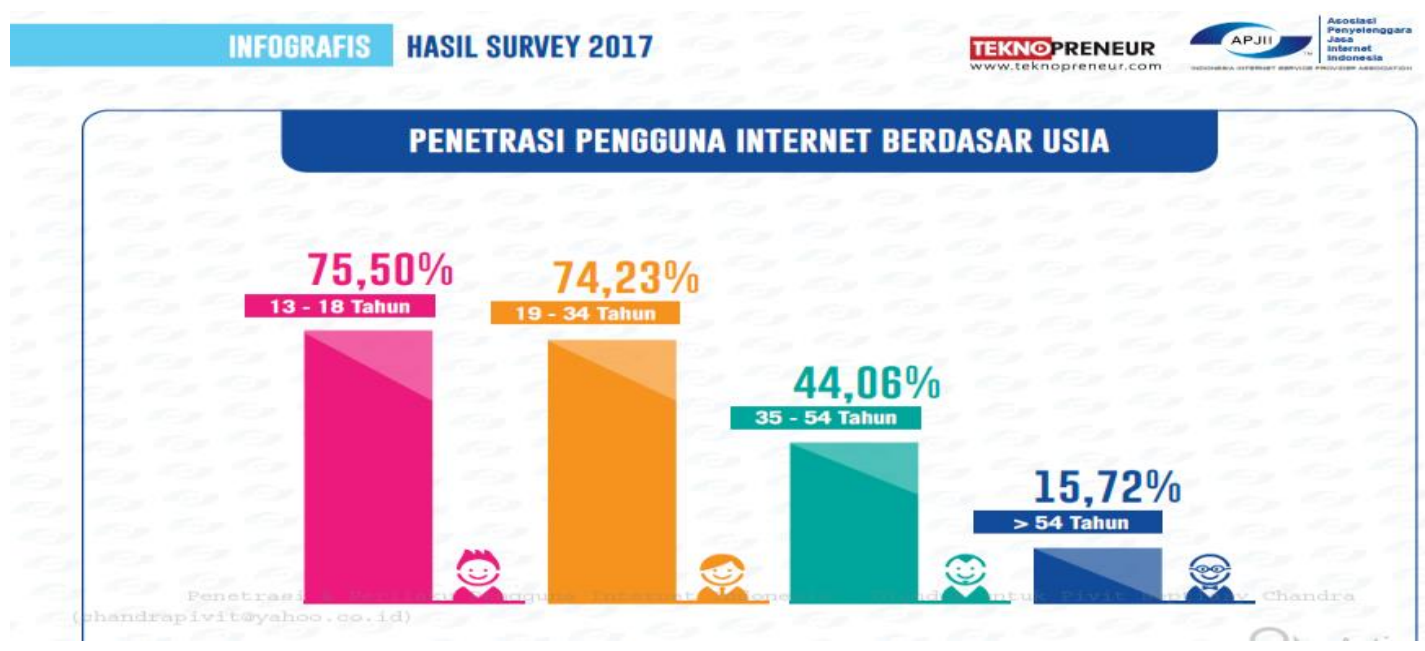

Gambar 4. Pengguna Internet Berdasarkan Usia

(Sumber : Asosiasi Penyelenggara Jasa Internet Indonesia (APJII) Tahun 2018)

Usia 13-18 tahun dikategorikan sebagai usia pada golongan remaja. Berdasarkan hasil persentase dari riset yang dilakukan oleh Asosiasi Penyelenggara Jasa Internet Indonesia (APJII), remaja merupakan pengguna internet terbesar di Indonesia. Melihat persentase dari penduduk berumur 10 tahun keatas dirinci menurut ijazah yang dimiliki dari tahun 2014-2017 berdasarkan data dari BPS Kota Pekanbaru tahun 2017 sangatlah besar tahun 2014 penduduk dengan pendidikan SD sekitar 10,11 persen; SLTP 17,48 Persen; SLTP 17,48 persen; dan SLTA 49,61 persen dan pada tahun 2017 terdapat perkembangan yang signifikan pada level pendidikan SD menjadi 18,38 persen sedangkan pada SLTP dan SLTA terdapat penurunan persentase menjadi 14,81 dan 38,06 persen.

Berdasarkan Asosiasi Penyelenggara Jasa Internet Indonesia diperoleh data statistik pengguna internet di Indonesia pada tahun 2012 mencapai 63 juta pengguna dan tahun 2013 telah meningkat menjadi 82 juta pengguna, Sedangkan berdasarkan data dari hasil penelitian yang berjudul“ Keamanan Penggunaan Media Digital pada Anak dan Remaja di Indonesia" yang dilakukan UNICEF dan Kementerian Komunikasi dan Informatika, pengguna internet di Indonesia yang berasal dari kalangan anak-anak dan remaja diprediksi mencapai 30 juta. Penelitian tersebut juga mencatat ada kesenjangan digital yang kuat antara anak dan remaja yang tinggal di perkotaan dengan yang tinggal di pedesaan. 
Kehadiran internet menjadi awal dari terbentuknya pola baru dalam interaksi sosial yaitu melalui media sosial, yang membuat setiap orang berpotensi menjadi komunikator massa. Setiap individu berpotensi untuk menyampaikan berbagai kejadian di belahan bumi tanpa harus membawa beritanya ke meja redaktur atau editor. Dapat pula digunakan untuk menunjang aktivitas rutin pengguna atau aktivitas lainnya. Hal ini merupakan lahan yang bagus untuk para pemula atau remaja dalam mencari dan mengembangkan diri mereka. Mencari informasi sebanyak-banyaknya untuk mendukung pengembangan potensi dan penunjang akvitas mereka tanpa memverifikasi tingkat kebenaran atas informasi tersebut. Sehingga dapat dikatakan bahwa, sosialisasi sosial yang dilakukan para remaja kini kapasitas nya lebih besar di dunia maya dengan fasilitas komputer, smartphone, internet dibandingkan dengan dunia nyata.

\section{Simpulan}

Dalam pengabdian masyarakat ini dapat menjelaskan bahwasanya manusia merupakan makhluk sosial yang saling membutuhkan satu dan lainnya. Zaman kini terdapat dua dimensi dalam bersosial yaitu dimensi kehidupan nyata dan dimensi kehidupan sosial. Dalam kehidupan sosial kita lakukan sebagaimana biasanya, namun dikehidupan maya kita membutuhkan media lainya untuk dapat berinteraksi, yaitu media sosial. Keterbatasan dalam pengabdian ini mencakup tata cara pelaksanaan yang dilaksanakan secara online/daring sehingga dampak dan feedback yang didapatkan belum terlihat jelas. Kegiatan ini diharapkan dapat dilaksanakan kembali dengan kondisi yang lebih baik sehingga peserta dapat secara langsung berinteraksi.

\section{Referensi}

Afriluyanto, T. R. (2018). Fenomena Remaja Menggunakan Media Sosial dalam Membentuk Identitas. KOMUNIKA: Jurnal Dakwah Dan Komunikasi, 11(2), 184-197. https://doi.org/10.24090/komunika.v11i2.1365

Al-Mighwar, M. (2006). Psikologi Remaja. Bandung: CV Pustaka Setia

Desmita, R. 2008. Psikologi Perkembangan. Bandung: PT.Remaja Rosdakarya

Karjaluoto, E. (2008, 01 Maret). A Prime in Social Media: examining the Phenomenon, itsRelevance, Promise and Risk. Diakses pada 20 November 2018 dari (http://www.smashlab.com/updates/a-primer-in-social-media/)

Kominfo. (2018.) Penetrasi pengguna Internet,

https://kominfo.go.id/index.php/content/detail/12640/siaran-pers-no-

53hmkominfo022018-tentang-jumlah-pengguna-internet-2017-meningkatkominfo-terus-lakukan-percepatan-pembangunan-broadband/0/siaran_pers. Diakses pada 8 September 2018

Pramiyanti, A., Putri, I. P., \& Nureni, R. (2014). Motif remaja dalam menggunakan media 
baru (studi pada Remaja di Daerah Sub-Urban Kota Bandung). KomuniTi, 6(2), 95103. http://journals.ums.ac.id/index.php/komuniti/article/download/2783/1776 Qomariyah, A. N. (2011). Perilaku Penggunaan Internet Dikalangan Remaja Diperkotaan. Jurnal UNAIR, 1-15.

Stren, S. (2002). Sexual Selves on the World Wide Web : Adolecents girl home page as sites for sexual self-expression. In J. D. Brown, J.E. Steele, \& K. Walsh Childers (Eds.), Sexual Media: Investigating Media's Influence on adolescents sexuality (pp.256-285). Mahwah, NJ: Lawrence Erlbaum Associates

Tracy, L. Q (1997). Sahabat Internet: pedoman Bagi Pemula Untuk Memasuki Jaringan Global. Bandung :ITB

Watie, E. D. S. (2016). Komunikasi dan Media Sosial (Communications and Social Media). Jurnal The Messenger, 3(2), 69. https://doi.org/10.26623/themessenger.v3i2.270 